\title{
Investigasi Faktor-Faktor yang Mempengaruhi Kualitas Tulisan Ilmiah Mahasiswa
}

\author{
M. Fadhly Farhy Abbas, Herdi \\ Universitas Lancang Kuning \\ fadhly@unilak.ac.id
}

\begin{abstract}
Abstrak: Penelitian ini didasari dengan adanya kebutuhan untuk mengevaluasi capaian pembelajaran mata kuliah yang berada dalam kategori Writing Skill, seperti: Paragraph Writing, Composition and Essay Writing, Argumentative Writing, dan Thesis Writing. Penelitian ini bertujuan untuk menganalisis faktor-faktor apa saja yang mempengaruhi kualitas tulisan ilmiah mahasiswa. Desain penelitian yang digunakan dalam penelitian ini adalah rancangan penelitian deskriptif. Data penelitian dikumpulkan dengan menggunakan questionnaire (angket) dan panduan wawancara. Yang menjadi partisipan dalam penelitian ini adalah alumni (lulusan) Program Studi Pendidikan Bahasa Inggris, Fakultas Keguruan dan Ilmu Pendidikan (FKIP) Universitas Lancang Kuning (UNILAK) pada Tahun Akademik 2020/2021. Jumlah alumni tersebut adalah sebanyak 36 orang. Data yang telah dikumpulkan melalui angket dan wawancara dianalisis secara deskriptif. Hasil penelitian ini menujukkan bahwa, terdapat faktor eksternal dan internal yang menghambat keterampilan menulis mahasiswa. Hal ini didukung oleh data dari wawancara bahwa kesulitan mahasiswa dalam menulis tulisan ilmiah itu, secara umumnya memang dipengaruhi oleh faktor eksternal dan internal tadi, seperti kurangnya rasa percaya diri, kurangnya pengetahuan dalam menemukan referensi bacaan, kurangnya pengetahuan dalam hal penggunaan tata bahasa, kosakata, dan mekanisme penulisan yang benar, serta minimnya waktu untuk latihan menulis. Berdasarkan temuan ini, dapat disimpulkan bahwa faktor eksternal dan internal menjadi faktor penentu dan yang paling berpengaruh terhadap kualitas tulisan ilmiah mahasiswa.

Kata kunci: Faktor internal; faktor eksternal; tulisan ilmiah; penelitian deskriptif
\end{abstract}

Abstract: This research is based on the need to evaluate the learning achievement of subjects in the Writing Skill category, such as: Paragraph Writing, Composition and Essay Writing, Argumentative Writing, and Thesis Writing. This study aims to analyze the factors that affect the quality of students' scientific writing. The research design used in this research was a descriptive research design. The data were collected using a questionnaire and interview guide. The participants in this study were alumni of the English Education Study Program, Faculty of Teacher Training and Education (FKIP), Universitas Lancang Kuning (UNILAK) in the 2020/2021 Academic Year. The number of alumni was 36 people. The data that has been collected through questionnaires and interviews were analyzed descriptively. The results of this study indicated that, there were external and internal factors that inhibited students' writing skills. This was supported by data from interviews that students' difficulties in writing scientific writings were generally influenced by external and internal factors, such as lack of self-confidence, lack of knowledge in finding references for writing, lack of knowledge in terms of using good grammar, vocabulary, and correct use writing mechanism, as well as lack of time for writing practice. Based on these findings, it can be concluded that external and 
internal factors are the determining factors and the most influential on the quality of students' scientific writing.

Keywords: Internal factor; external factor; scientific writing; descriptive research

\section{Pendahuluan}

Aktivitas menulis merupakan suatu kegiatan yang kompleks. Hal tersebut dikarenakan kegiatan menulis ini harus mengacu kepada writing process dan micro-macro skills dari pada kegiatan menulis tersebut (Fachrurrazy, 2011). Selain itu, unsur lain yang harus dipenuhi dalam kegiatan menulis adalah unity dan coherence (Oshima dan Hogue, 2006), (Butler, 2014), (Hogue, 2014), (Oshima dan Hogue, 2014a), (Oshima dan Hogue, 2014b). Unsur-unsur tersebut membuat suatu tulisan menjadi baik dan sempurna. Semakin lengkap unsur-unsur tulisan yang terkandung di dalam sebuah tulisan ilmiah, akan semakin baik dan sempurna pula kualitas tulisan ilmiah tersebut. Dengan kata lain, penelitian tentang menulis atau tulisan ilmiah ini sangat menarik untuk diangkat menjadi suatu topik penelitian.

Sehubungan dengan pernyataan di atas, tulisan ilmiah pada saat ini kurang diminati oleh sebagian orang yang tidak berada dalam kegiatan penelitian atau pengajar di perguruan tinggi. Terlebih lagi, tulisan ilmiah mahasiswa yang sudah menjadi salah satu persyaratan untuk lulus pada jenjang strata satu pada level perguruan tinggi. Umumnya para mahasiswa tersebut merasa terbebani dengan adanya tulisan ilmiah seperti ini. Survei awal tentang masalah dalam tulisan ilmiah mahasiswa ini sudah dilakukan sebelumnya untuk melihat kemampuan mahasiswa dalam menulis salah satu tulisan ilmiah, yakni hasil penelitian tentang menulis suatu proposal penelitian yang dilakukan oleh (Abbas: 2015).

Hasil dalam penelitian (Abbas, 2015) tersebut menunjukkan kemampuan mahasiswa dalam menulis proposal penelitian masih pada level "middle". Yang berarti kemampuan mahasiswa dalam menulis tulisan ilmiah masih belum mencapai nilai yang memuaskan. Berdasarkan hasil penelitian ini, peneliti tertarik ingin menginvestigasi lebih lanjut tentang faktor-faktor yang mempengaruhi kualitas tulisan ilmiah mahasiswa tersebut. Terdapat banyak yang mendukung tentang tulisan ilmiah ini, salah satu acuan peneliti dalam membuat penelitian mengenai faktor adalah dengan membuat questionnaire (angket) untuk mencari jawaban faktor yang mempengaruhi kualitas tulisan ilmiah mahasiswa.

Dengan acuan questionnaire, peneliti dapat menggunakannya dalam melihat faktor apa saja yang mempengaruhi kualitas tulisan ilmiah mahasiswa. Dalam hal ini, tulisan ilmiahnya menggunakan bahasa Inggris, dikarenakan peneliti fokus kepada mahasiswa Program Studi Pendidikan Bahasa Inggris dalam penulisan ilmiah dengan melihat faktor yang mempengaruhinya. Diharapkan setelah peneliti menginvestigasi faktor yang mempengaruhi kualitas tulisan ilmiah, peneliti akan dapat mengevaluasi pengajaran yang berhubungan dengan mata kuliah writing skill dengan memperhatikan faktor utama yang menjadi masalah tersebut.

Lebih lanjut, (Nugroho, 2011) menyatakan bahwa ada 7 faktor yang mempengaruhi penulisan karya tulis ilmiah hingga tulisan tersebut terbit atau published menurut. Yang pertama adalah adanya bakat dalam menulis. Bakat merupakan faktor pendukung ketika seseorang ingin menulis suatu tulisan ilmiah. Akan tetapi, bisa jadi faktor penghambat, ketika seseorang merasa dirinya tidak berbakat dalam menulis sehingga hal ini menjadi faktor penghambat baginya. Kemudian, yang kedua adalah faktor pengetahuan, yang ketiga adalah rasa percaya diri, yang keempat adalah takut/tidak dengan kritikan orang lain, yang kelima 
adalah faktor ketersediaaan waktu dalam menuli, yang keenam adalah faktor pengetahuan perihal publikasi tulisan, dan yang ketujuh adalah faktor diterima/ditolak oleh redaksi. Seorang penulis akan enggan membuat tulisan ilmiah jika tulisan ilmiah tersebut ditolak pada redaksi jurnal tertentu.

Menyambung hal di atas, ada beberapa penelitian terdahulu yang relevan dengan penelitian ini untuk mendukung teori-teori yang digunakan dalam penelitian ini. Penelitian yang relevan tersebut adalah penelitian yang dilakukan oleh (Abbas dan Yusuf, 2020; Abbas dan Asy'ari, 2019; Abbas dan Herdi, 2018; Abbas 2015; Fajri, 2016; Fahim dan Rad, 2012; Gupta dan Woldemariam, 2011). Berdasarkan ulasan tentang sejumlah penelitian yang relevan ini, peneliti tertarik untuk melakukan penelitian lanjutan yang berfokus pada faktor-faktor yang mempengaruhi kualitas tulisan ilmiah mahasiswa. Hal ini karena penelitian tentang faktor-faktor yang mempengaruhi kualitas tulisan ilmiah ini belum diteliti oleh penelitipeneliti di atas.

Sejalan dengan dengan pernyataan di atas, peneliti tertarik untuk melakukan sebuah penelitian guna menginvestigasi faktor apa saja yang mempengaruhi kualitas tulisan ilmiah mahasiswa. Penelitian ini memberikan gambaran tentang faktor yang mempengaruhi kualitas tulisan ilmiah mahasiswa Program Studi Pendidikan Bahasa Inggris, untuk kemudian dapat digunakan sebagai bahan evaluasi mata kuliah yang berhubungan Writing Skill. Selanjutnya, rumusan masalah dalam penelitian ini dapat ditulisakan dalam bentuk pertanyaan sebagai berikut: Faktor apa saja yang mempengaruhi kualitas tulisan ilmiah mahasiswa Program Studi Pendidikan Bahasa Inggris?

\section{Metode Penelitian}

Desain penelitian yang digunakan dalam penelitian ini adalah rancangan penelitian deskriptif. Selanjutnya, tahapan penelitian ini adalah sebagai berikut: (1) peneliti menyiapkan lembar questionnaire (angket) dan panduan wawancara sebagai instrumen atau alat untuk mengumpulkan data. (2) mahasiswa diminta untuk mengisi angket yang sudah disiapkan. (3) mahasiswa diminta untuk memberikan respon atas pertanyaan yang diberikan dalam bentuk wawancara untuk mendukung data yang dikumpulkan melalui angket. (4) peneliti melakukan analisis dan memberikan penilaian terhadap hasil angket dan wawancara tersebut mengenai faktor yang mempengaruhi kualitas tulisan ilmiah mahasiswa. (5) Peneliti menyimpulkan faktor apa saja yang mempengaruhi kualitas tulisan ilmiah mahasiswa.

Penelitian ini dilakukan di Program Studi Pendidikan Bahasa Inggris, Fakultas Keguruan dan Ilmu Pendidikan (FKIP), Universitas Lancang Kuning (UNILAK) yang terletak di Jl. Yos Sudarso KM. 08 Pekanbaru-Riau. Selanjutnya, yang menjadi partisipan dalam penelitian ini adalah alumni (lulusan) Program Studi Pendidikan Bahasa Inggris, Fakultas Keguruan dan Ilmu Pendidikan (FKIP) Universitas Lancang Kuning (UNILAK) pada Tahun Akademik 2020/2021. Jumlah alumni tersebut adalah sebanyak 36 orang.

Pengumpulan data dilakukan dengan menggunakan questionnaire (angket) dan wawancara sebagaimana yang sudah dijelaskan sebelumnya. Dalam penelitian ini, mahasiswa diminta untuk mengisi angket yang dibagikan secara online melalui media google form berdasarkan petunjuk atau instruksi pengisian angket yang sudah disajikan. Selanjutnya, peneliti melakukan wawancara terbuka kepada partisipan berdasarkan sepuluh (10) pernyataan yang terdapat pada angket untuk menemukan faktor pendukung dari hasil angket sebelumnya. 
Setelah data dikumpulkan melalui instrumen penelitian yang sudah dijelaskan sebelumnya, peneliti menganalisis serta memberikan penilaian terhadap hasil angket dan wawancara secara deskriptif. Peneliti mendeskripsikan hasil angket dan wawancara secara luas untuk menemukan faktor apa saja yang mempengaruhi kualitas tulisan ilmiah mahasiswa. Sehingga, hasil penelitian ini dapat memberikan kontribusi positif terhadap proses evaluasi mata kuliah writing skill.

\section{Hasil dan Pembahasan}

Berdasarkan data yang dikumpulkan melalui angket, dapat dilihat beragam respon dari mahasiswa. Ada yang memilih respon "sangat setuju, setuju, ragu-ragu, tidak setuju, dan sangat tidak setuju" terhadap pernyataan yang disampaikan melalui angket tersebut. Respon mahasiswa ini terkait dengan faktor-faktor yang mempengaruhi kualitas tulisan ilmiah yang dituliskannya. Selanjutnya, hasil angket tersebut dapat disajikan dalam bentuk tabel 1.

\section{Tabel 1 Rekapitulasi dan Persentase Respon Mahasiswa terhadap Angket}

\begin{tabular}{ccccccccccc} 
Pernyataan & \multicolumn{4}{c}{ Respon $(\%)$} & \multicolumn{4}{c}{ Jumlah Respon (Orang) } \\
& SS & S & RR & TS & STS & SS & S & RR & TS & STS \\
\hline 1 & 8.3 & 13.9 & 11.1 & 36.1 & 30.6 & 3 & 5 & 4 & 13 & 11 \\
2 & 8.3 & 47.2 & 5.6 & 36.1 & 2.8 & 3 & 17 & 2 & 13 & 1 \\
3 & 2.8 & 5.6 & 8.3 & 69.4 & 13.9 & 1 & 2 & 3 & 25 & 5 \\
4 & 2.8 & 16.7 & 5.6 & 61.1 & 13.9 & 1 & 6 & 2 & 22 & 5 \\
5 & 2.8 & 50 & 11.1 & 27.8 & 8.3 & 1 & 18 & 4 & 10 & 3 \\
6 & 11.1 & 27.8 & 8.3 & 41.7 & 11.1 & 4 & 10 & 3 & 15 & 4 \\
7 & 2.8 & 38.9 & 19.4 & 25 & 13.9 & 1 & 14 & 7 & 9 & 5 \\
8 & - & 5.6 & 2.8 & 50 & 41.7 & - & 2 & 1 & 18 & 15 \\
9 & 11.1 & 41.7 & 27.8 & 13.9 & 5.6 & 4 & 15 & 10 & 5 & 2 \\
10 & 19.4 & 66.7 & 2.8 & 11.1 & - & 7 & 24 & 1 & 4 & - \\
Average & 6.94 & 31.4 & 10.2 & 37.2 & 14.1 & 2.5 & 11.3 & 3.7 & 13.4 & 5.1 \\
Max & 19.4 & 66.7 & 27.8 & 69.4 & 41.7 & 7 & 24 & 10 & 25 & 15 \\
Min & 2.8 & 5.6 & 2.8 & 11.1 & 2.8 & 1 & 2 & 1 & 4 & 1 \\
\hline
\end{tabular}

\begin{tabular}{lll}
\multicolumn{1}{l}{ Keterangan } & \\
SS & & : Sangat Setuju \\
S & & : Setuju \\
RR & : Ragu-ragu \\
TS & : Tidak Setuju \\
STS & : Sangat Tidak Setuju \\
Average & : Nilai rata-rata \\
Max & : Nilai/angka terbesar \\
Min & : Nilai/angka terkecil
\end{tabular}

Berdasarkan Tabel 1, dapat dilihat bahwa respon "tidak setuju" adalah respon yang paling banyak dipilih oleh mahasiswa. Hal ini berarti bahwa, dari pernyataan 1-10 yang tertera 
dalam angket, respon "tidak setuju" adalah respon yang paling tinggi persentasenya, yaitu $37.2 \%$. Kemudian, jika diurutkan dari atas ke bawah, maka dapat dilihat bahwa untuk respon "sangat setuju" persentase rata-ratanya adalah "6.94\%". Lalu, untuk respon "setuju" persentase rata-ratanya adalah $31.4 \%$, untuk respon "ragu-ragu" sebanyak $10.2 \%$, untuk respon "tidak setuju" sebanyak $37.2 \%$, dan untuk repon "sangat tidak setuju" adalah sebanyak 14.1\%. Dari besaran persentase ini, jelas terlihat bahwa respon "tidak setuju" adalah respon yang paling besar persentasenya, yaitu $37.2 \%$.

Seiring dengan persentase rata-rata di atas, dapat juga dilihat persentase terbesar dari masing-masing respon. Untuk respon "sangat setuju", persentese terbesarnya adalah 19.4\%. Kemudian, untuk respon "setuju" persentese terbesarnya adalah $66.7 \%$, untuk respon "raguragu" persentese terbesarnya adalah $27.8 \%$, untuk respon "tidak setuju" persentese terbesarnya adalah $69.4 \%$, dan untuk respon "sangat tidak setuju" persentese terbesarnya adalah $41.7 \%$.

Sejalan dengan persentase terbesar, dapat juga dilihat persentase terkecil dari masingmasing respon yang dipilih oleh mahasiswa. Untuk respon "sangat setuju", persentese terkecilnya adalah $2.8 \%$. Kemudian, untuk respon "setuju" persentese terkecilnya adalah $5.6 \%$, untuk respon "ragu-ragu" persentese terkecilnya adalah $2.8 \%$, untuk respon "tidak setuju" persentese terkecilnya adalah $11.1 \%$, dan untuk respon "sangat tidak setuju" persentese terkecilnya adalah $2.8 \%$.

Berdasarkan paparan data berupa persentase di atas, dapat pula dilihat angka terbesar dan angka terkecil dari jumlah mahasiswa yang ada. Jika diurutkan dari atas hingga ke bawah, untuk respon "sangat setuju", angka terbesarnya adalah 7 dan angka terkecilnya adalah 1 . Kemudian, untuk respon "setuju", angka terbesarnya adalah 24 dan angka terkecilnya adalah 2. Lalu, untuk respon "ragu-ragu", angka terbesarnya adalah 10 dan angka terkecilnya adalah 1. Setelah itu, untuk respon "tidak setuju", angka terbesarnya adalah 25 dan angka terkecilnya adalah 4. Terakhir, untuk respon "sangat tidak setuju", angka terbesarnya adalah 15 dan angka terkecilnya adalah 1. Dari pemaparan ini, jelas terlihat bahwa angka terbesar dalam memilih respon itu adalah 25, dan itu merupkann kategori respon "tidak setuju" atas pernyataan yang tersedia pada angket.

Berdasarkan pemaparan hasil angket yang sudah dijelaskan, hasil angket ini dapat juga disajikan dalam bentuk diagram agar bisa terlihat lebih sederhana dan menarik. Selanjutnya, dapat disajikan 3 diagram yang menyajikan data tentang rata-rata persentase, nilai atau persentase tertinggi, dan persentase terendah. Selanjutnya, ketiga buah diagram ini dapat dilihat pada Gambar 1.

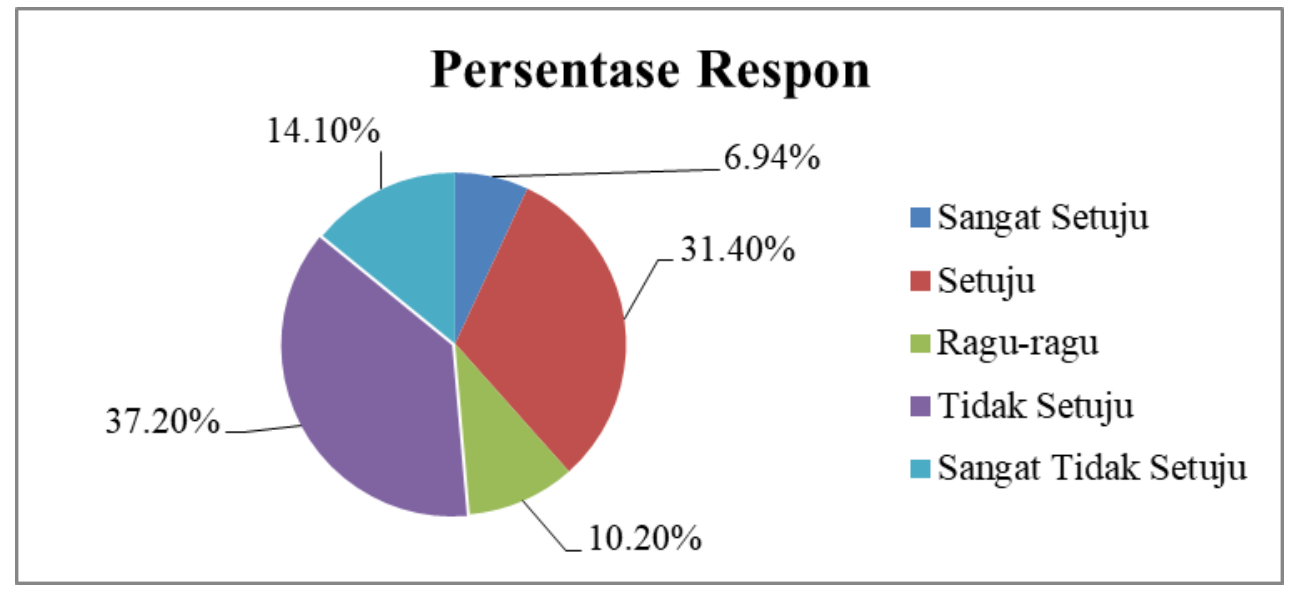




\section{Gambar 1 Rata-rata Persentase Respon}

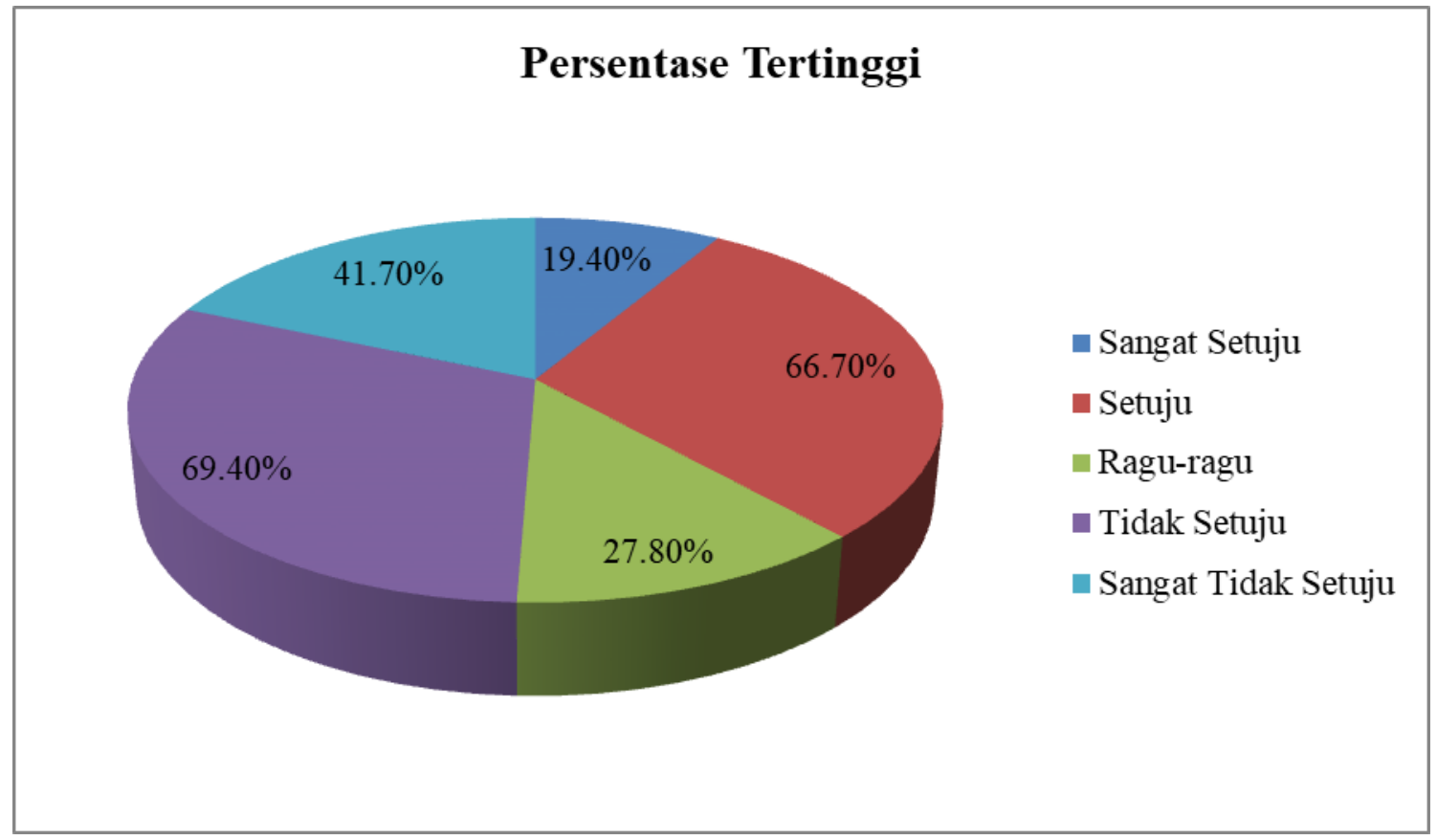

Gambar 2 Persentase Tertinggi

\section{Persentase Terendah}

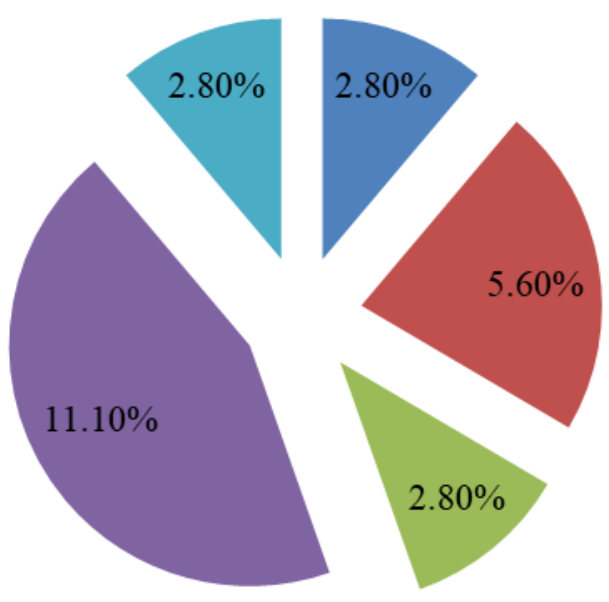

$$
\begin{aligned}
& \text { - Sangat Setuju } \\
& \text { - Setuju } \\
& \text { - Ragu-ragu } \\
& \text { - Tidak Setuju } \\
& \text { } \text { Sangat Tidak Setuju }
\end{aligned}
$$

Gambar 3 Persentase terendah 
Berdasarkan tiga buah gambar yang sudah disajikan sebelumnya, dapat dilihat bahwa rata-rata persentase respon mahasiswa terhadap angket adalah sebesar $6.94 \%$ yang menyatakan "sangat setuju", 31.4\% menyatakan "setuju", 10.2\% menyatakan "ragu-ragu", $37.2 \%$ menyatakan "tidak setuju", dan $14.1 \%$ menyatakan "sangat tidak setuju". Kemudian, untuk persentase tertinggi sebesar 69.4\% menyatakan "tidak setuju", dan untuk persentase terkecil sebesar 2.8\% menyatakan "ragu-ragu", "sangat setuju", dan "sangat tidak setuju". Dari pemaparan data ini dapat dinyatakan bahwa mahasiswa lebih cenderung memilih respon "tidak setuju" untuk pernyataan yang sifatnya negatif, dan "setuju" untuk pernyataan yang sifatnya positif yang tertera pada angket.

Sejalan dengan data dari angket, dapat juga dipaparkan data-data yang diperoleh dari panduan wawancara. Berdasarkan hasil wawancara tersebut, diperoleh informasi secara keseluruhan bahwa yang mempengaruhi kualitas tulisan ilmiah mahasiswa itu adalah faktor eksternal dan internal yang datang dari mahasiswa itu sendiri. Mahasiswa mengakui bahwa mereka memiliki rasa percaya diri yang kurang terhadap kemampuan menulisnya. Lalu, mahasiswa juga merasa memiliki pengetahuan yang kurang dalam menemukan referensi bacaan, menggunakan tata bahasa, kosakata, dan mekanisme penulisan yang benar pada tulisan yang dibuatnya. Terakhir, mahasiswa merasa bahwa waktu mereka untuk berlatih menulis itu sangat kurang. Mereka hanya berlatih menulis ketika pembelajaran berlangsung di kelas bersama dosennya. Ketika, pembelajaran di kelas usai, mereka sudah tidak pernah berlatih menulis lagi. Hal-hal seperti ini lah yang memepengaruhi kualitas tulisan ilmiah mahasiswa tersebut.

Berdasarkan hasil temuan dari penelitian ini, dapat diperjelas kembali bahwa kualitas tulisan ilmiah itu pada dasarnya adalah ditentukan oleh baiknya kemampuan mahasiswa tersebut dalam menulis. Hal ini sejalan dengan penelitian yang dilakukan oleh (Abbas dan Herdi, 2018; Fajri, 2016; Ahmed, 2010). Berdasarkan hasil penelitian mereka, ditemukan bahwa baiknya kemampuan menulis mahasiswa/siswa itu dipengaruhi oleh baiknya kemampuan mahasiswa/siswa tersebut dalam mengaplikasikan unsur menulis seperti Unity, Coherence, Grammar, Vocabulary, Mechanics, dan lain sebagainya di dalam tulisan atau karangan yang dibuat oleh mahasiswa/siswa tersebut.

Disamping kemampuan yang baik dalam menulis, faktor-faktor lain yang mendukung kemampuan mahasiswa dalam menulis juga sangat menentukan kualitas tulisan ilmiah mahasiswa tersebut. Sebut saja faktornya adalah motivasi, minat, bakat, rasa percaya diri, rajin, dan lain sebagainya. Tidak dipungkiri bahwa pintar dan memiliki kemampuan yang baik dalam menulis saja, akan dapat menghasilkan sebuah tulisan ilmiah yang bagus. Tentu, kepintaran dan kepandaian tadi hendaknya didukung oleh pemikiran tentang menulis yang positif, motivasi menulis yang tinggi, rasa percaya diri yang tinggi, serta didukung oleh faktorfaktor lain yang sudah disebutkan tadi.

Sejalan dengan faktor yang menentukan kualitas tulisan ilmiah mahasiswa, (Fahim dan Rad, 2012 telah menemukan dalam hasil penelitiannya bahwa siswa yang memiliki pikiran yang positif terhadap kemampuan menulis, akan mampu menghasilkan sebuah tulisan yang baik pula. Semakin baik pola pemikiran siswa tersebut terhadap keterampilan menulis, akan semakin baik pula keterampilan menulis yang dihasilkannya. Selanjutnya, (Gupta dan Woldemariam, 2011) juga menemukan hal senada bahwa sikap yang positif terhadap suatu 
strategi menulis, akan mampu melahirkan sebuah tulisan yang baik pula. Namun, hal ini dilakukan dengan dukungan motivasi yang tinggi tentunya. Hal ini menunjukkan bahwa, untuk bisa menulis dengan baik, diperlukan motivasi dan rasa percaya diri yang tinggi, serta sikap dan pemikiran yang positif.

Meskipun kualitas tulisan ilmiah mahasiwa ini dipengaruhi oleh banyak faktor, baik itu faktor eksternal maupun faktor internal, perlu juga dicarikan solusinya agar faktor-faktor yang sudah dipaparkan tadi tidak lagi mengganggu kualitas tulisan ilmiah mahasiwa tersebut. Sebagai contoh, perlu dilakukan penelitian lanjutan seperti penelitian tindakan kelas atau penelitian ekperimen yang fokusnya adalah untuk mengatasi faktor-faktor yang mempengaruhi kualitas tulisan ilmiah mahasiswa tersebut. Sehingga, faktor-faktor yang mempengaruhi kualitas tulisan ilmiah mahasiswa tersebut tidak lagi menghambat kemampuan mahasiswa dalam menulis, dan mahasiswa pun dapat menghasilkan tulisan ilmiah yang berkualitas baik.

\section{Kesimpulan dan Saran}

Berdasarkan hasil temuan dan pembahasan dalam penelitian ini, dapat disimpulkan bahwa faktor eksternal dan internal menjadi faktor penentu dan yang paling berpengaruh terhadap kualitas tulisan ilmiah mahasiswa. Hal ini ditunjukkan oleh besarnya persentase respon mahasiswa yang memilih pernyataan tentang faktor eksternal dan internal ini. Serta, hal ini didukung juga oleh hasil wawancara kepada mahasiswa bahwa memang faktor eksternal dan internal menjadi salah satu faktor penghambat terbesar dan yang paling berpengaruh dalam menulis tulisan ilmiah.

Sejalan dengan kesimpulan di atas, ada beberapa saran yang dapat dikemukakan sebagai berikut. Pertama, mahasiswa yang menjadi partisipan dalam penelitian ini disarankan untuk sering berlatih dan menguasai lagi tips menulis tulisan ilmiah dengan baik. Sehingga, kemampuan mahasiswa dalam menulis esai dapat dipertahankan atau ditingkatkan menjadi jauh lebih baik lagi. Kedua, dosen yang mengampu mata kuliah Writing disarankan untuk memberikan bimbingan dan latihan yang lebih intens lagi kepada mahasiswa, khususnya yang nilainya masih jauh dari harapan agar kemampuan mahasiswa tersebut dapat ditingkatkan menjadi lebih baik lagi. Ketiga, peneliti selanjutnya yang ingin melakukan penelitian yang berkaitan dengan topik penelitian ini dapat menjadikan hasil penelitian ini sebagai bahan rujukan dan setiap teori yang digunakan dalam penelitian ini dapat pula digunakan sebagai rujukan untuk melakukan penelitian lanjutan dengan metode dan rancangan penelitian yang berbeda, seperti rancangan Penelitian Tindakan Kelas (PTK), Eksperimen, atau Penelitian dan Pengembangan (Research and Development/R\&D).

\section{Daftar Pustaka}

Abbas, M. F. F., \& Yusuf, S. S. M. D. (2020). The Effect of Edmodo in Triggering Students' Recognition of Recount Text Elements. Lectura: Jurnal Pendidikan, 11(1), 142-152.

Abbas, M. F. F., \& Asy'ari, N. F. (2019). Mixed Method: Students' Ability in Applying Writing Mechanics in Analytical Exposition Text. ELT-Lectura, 6(2), 147-157.

Abbas, M. F. F., \& Herdi, H. (2018). Analisis Kemampuan Menulis Esai Argumentatif Mahasiswa Semester 5 Prodi Pendidikan Bahasa Inggris FKIP UNILAK Tahun Akademik 2017/2018. Lectura: Jurnal Pendidikan, 9(1), 28-34.

Abbas, M. F. F. (2015). Analysis of Students' Ability in Writing a Research Proposal. Dikutip dari ELT-Lectura Journal, Vol. 2 No.2; 44-47. 
Ahmed, A. H. (2010). Students' Problems with Cohesion and Coherence in EFL Essay Writing in Egypt: Different Perspectives. Dikutip dari Literacy Information and Computer Education Journal (LICEJ), Volume 1, Issue 4, 211-221.

Butler, L. (2014). Longman Academic Writing Series: Sentences to Paragraphs (1 ${ }^{\text {st }}$ edition). White Plains, New York: Pearson Education.

Fachrurrazy. (2011). Teaching English as a Foreign Language for Teachers in Indonesia. Malang: Universitas Negeri Malang Press.

Fahim, M. \& Rad, S.K. (2012). The Relationship between Self-Esteem and Paragraph Writing of Iranian EFL Learners. Dikutip dari Scientific Research Journal of Psychology, Volume. 3 No. 1, 24-29.

Fajri, N. (2016). Assessing Unity, Coherence and Word Usage in Students' Writing. Dikutip dari English Education Journal (EEJ), 7(1), 102-116.

Gupta, D. \& Woldemariam, G.S. (2011). The Influence of Motivation and Attitude on Writing Strategy Use of Undergraduate EFL Students: Quantitative and Qualitative Perspectives. Asian EFL Journal, Volume 13, Issue 2, 34-89.

Hogue, A. (2014). Longman Academic Writing Series: Paragraphs ( $3^{\text {rd }}$ edition). White Plains, New York: Pearson Education.

Nugroho, H. (2011). Cara Mudah Menjadi Guru Penulis. Semarang: Dahara Prize.

Oshima, A. \& Hogue, A. (2006). Writing Academic English (4 ${ }^{\text {th }}$ edition). New York: Pearson Longman.

Oshima, A. \& Hogue, A. (2014a). Longman Academic Writing Series: Paragraphs to Essays ( $4^{\text {th }}$ edition). New York: Pearson Longman.

Oshima, A. \& Hogue, A. (2014b). Longman Academic Writing Series: Essays (5 ${ }^{\text {th }}$ edition). New York: Pearson Longman. 